\title{
IAMJ
}

INTERNATIONAL

AYURVEDIC

MEDICAL JOURNAL

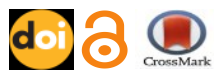

Review Article

ISSN: 23205091

Impact Factor: 5.344

\section{MENOPAUSE (RAJO NIVRUTTI) AND OBESITY (STHOULYA) - A CRITICAL REVIEW}

\author{
Usha K S ${ }^{1}$, Gurdip Singh²
}

${ }^{1}$ Professor, Department of Swasthavritta \& Yoga,

SDM Institute of Ayurveda \& Hospital, Bangalore - 560074, Karnataka, India,

${ }^{2}$ Director, $\mathrm{PG}$ and $\mathrm{PhD}$ Studies,

SDM College of Ayurveda and Hospital, BM Road, Tanniru halla, Hassan-573201, Karnataka, India

Corresponding Author: dr.ushaks@gmail.com

\section{https://doi.org/10.46607/iamj2408112020}

(Published online: November 2020)

Open Access

(C) International Ayurvedic Medical Journal, India 2020

Article Received: 23/10/2020 - Peer Reviewed: 02/11/2020 - Accepted for Publication: 11/11/2020

Check for updates

\section{ABSTRACT}

Obesity has reached epidemic proportions in the recent years. Modern lifestyle and dietary habits often take the blame for its rise. Obesity acts as a risk factor for many non-communicable diseases like diabetes mellitus, cardiovascular diseases, cancer, hypertension. Obesity is also outcome of many changes in the body. One of the causes of obesity in female population is menopause. Since menopause brings along with it a plethora of ailments, obesity is treated as any other lifestyle disorder. There is a need to study Sthoulya (obesity) through the aetiological factor mentioned by Charaka as Javoparodha or explained by Chakrapani as Jaroparodha- early onset of old age. There is an urgent need to treat obesity from the perspective of menopause. Menopause can occur at any age from 45-55 years. But the aftereffects of menopause may persist well into the age of 65-70 years. In the next decade there will be a rise in the geriatric population by $56 \%$ in the world. In India geriatric population will be $12.5 \%$ of the total population. According to the national census of 2011 in India, there are 53 million females in the elderly population compared to the male population of 51 million. The female geriatric population may have a completely different set of ailments compared to that of male geriatric population. Hence Sthoulya due to menopause should be considered a separate disease entity and the management should be that of hormonal rehabilitation than just replacement.

Keywords: Obesity, Menopause, Hormones, Sthoulya, Rajo Nivrutti, Jaroparodha 


\section{INTRODUCTION}

In case of menopause, women who earlier did not fall into the category of obesity suddenly find themselves in this group. The lifestyle which seemed perfect till now seems to be the culprit. Menopause in itself brings about many other ailments in the form of menopausal syndrome. The classical texts determine the age of menopause around fifty years. Sthoulya (obesity) is considered one among the eight despicable personalities (Ashta Nindita Purusha) by Charaka. An analysis of these body types reveals that these body types are related to hyper or hypo secretion of endocrine glands and or due to deficiency of micronutrients. Sthoulya in general is considered to be due to lethargic lifestyle and due to genetic makeup. Rajo Nivrutti (cessation of menstruation) is the main cause for obesity in menopausal stage. Sthoulya is related to increase in Medo Dhatu (adipose tissue) and Rajo Nivrutti heralds the onset of Vardhakya (old age) associated with Dhatu Kshaya ${ }^{1}$ (depletion of body tissues). The causes appear to contradict one another.

A comprehensive understanding of Sthoulya and Rajo Nivrutti would shed light on the problem and treating menopausal obesity as a separate entity would make the management of Rajo Nivrutti Janya Sthoulya (menopausal obesity) easy.

\section{Sthoulya and Rajo Nivrutti:}

The causes for Sthoulya enumerated by Charaka include excessive intake of food, intake of high calorie diet which is heavy for digestion, sweet in taste, cold and unctuous in nature; lack of physical exercise, abstinence from sexual intercourse, indulgence in day time sleep, excessive cheerfulness, lack of mental worry and genetic predisposal. The features of obesity according to Charaka include shortening of lifespan, difficulty in movements or sluggish movements (But interpreted as early onset of old age by Chakrapani), difficulty in sexual intercourse, general debility, foul smell from the body, excessive sweating, excessive hunger and excessive thirst ${ }^{2}$. Sushruta explains that Rasa dhatu (chyle) is the sole cause for both Sthoulya and Karshya (emaciation). In a person who takes food that increases Kapha (Kapha humor), one who takes food before the previous meal is digested, one who does not indulge in physical exercise, one who indulges in day time sleep, the incomplete Annarasa (undigested food) in Ama (product of incomplete digestion and metabolism) condition affects the body wherever it circulates with its sweet taste, and gives rise to Meda because of its unctuousness and causes excessive Sthoulya. The person thus affected will suffer from breathlessness, excessive thirst, excessive hunger, excessive sleep, excessive perspiration, excessive foul smell of the body, phlegm in the throat, general debility and unclear speech rapidly. Medo Dhatu (adipose tissue) Vruddhi Lakshana (features of excess) as enumerated by Vagbhata includes Mamsa Vruddhi Lakshanas (excess of muscular tissue) like goitre, malignant growth, tumours, excessive growth in thighs and abdomen, excess of mass in neck region. In addition, Medo Dhatu excess includes fatigue, breathlessness on exertion, sagging of hips, breasts and abdomen ${ }^{3}$.

The complications arising due to obesity enumerated by Vagbhata are Apachi (various types of tumours), Meha (Diabetes mellitus and other diseases of the urinary system), Jwara (fever), Udara (ascites), Bhagandara (fistula in ano), Kasa (cough), Sanyasa (coma), Ama condition (disorder of digestion and metabolism) difficult to treat and Kushtha (skin diseases) ${ }^{4}$. Among other causes of Sthoulya, Rajo Nivrutti has to be taken as the main etiological factor. Sushruta and Vagbhata have mentioned the age of Rajo Nivrutti as fifty years ${ }^{5,}$. Charaka states that the pathology of Sthoulya is Vata (Vata humor) getting fuelled my Medodhatu in increasing the Agni (digestive fire) of a person which again leads to over consumption of food. Therefore, the Vata predominance during the Jara Kala (old age) is more detrimental in the context of Shtoulya due to Rajo Nivrutti. Sushruta as well as Vagbhata have mentioned that Artava is a form of Rasa Dhatu (blood and plasma tissue). Sushruta goes on to mention that Artava is Agneya (possessing fire element) in nature. So, the deficiency of Agni Maha Bhuta (fire element) brings about Rajo Nivrutti.

\section{Obesity in menopause and hormones:}

The hormones related with satiety include steroid hormones which are sex hormones. They include 
oestrogens (oestradiol, oestrone and oestriol), progesterone and testosterone. The adrenal hormones include DHEA(Dehydroepiandrosterone) and cortisol. Women tend to have fat stores in the form of subcutaneous fat around the hips and in the breasts. When there is rise in oestrogen levels, excessive fat deposition occurs primarily around the hips and thighs leading to the typical pear-shaped body which is gynoid obesity. In postmenopausal phase, the oestrogen levels become very low and testosterone levels continue to be produced by the ovaries and adrenals. At the level of tissue or cell, oestrogen rules over the testosterone before menopause. After menopause oestrogen / testosterone ratio shifts to testosterone dominance. This results in androgen excess. The fat distribution is androgynous in nature or apple shaped where the visceral fat is stored in the belly in the interstitial space. The fat tissue acts as an endocrine organ and consists of aromatase. This converts testosterone to oestradiol and androstenedione to oestrone. In obese women of postmenopausal phase, the predominant form of oestrogen is oestrone and not oestradiol. Oestrone is ten times less potent compared to oestradiol. Presence of oestrone and absence of oestradiol is the hallmark of menopause. DHEA is a precursor for the production of oestrogen and testosterone in tissues. Its concentration in the body is more compared to other steroid hormones. One of the natural metabolite of DHEA,7-keto DHEA is known to increase the metabolic rate and helps in weight loss according to some studies. Progesterone balances and optimizes the effects of oestrogen. Increase in appetite and food intake may be caused by progesterone. Excess production of progesterone may increase insulin resistance which in turn promotes fat storage. In chronic stress condition, the effect of cortisol on blood sugar results in increased appetite and craving for carbohydrates. It also results in storage of more glucose as fat in the visceral area. This visceral fat has more cortisol receptors than other types of fat tissue. Thus, hormones affect weight gain which in turn affects hormone balance ${ }^{7}$. Oestrogens are transferred to adipose tissue cells and liver cells by endocrine and paracrine pathway. They are produced in these cells by androgens. Oestrogen receptors are present in adipocytes and hepatocytes in a lesser density compared to that in gonads. On cellular level, oestrogens regulate mRNA (messenger ribonucleic acid) production for particular proteins which are involved in lipid metabolism. In adipose tissue, 17- beta oestradiol has a direct effect on lipo protein lipase (LPL) and hormone sensitive lipase (HSL). The indirect action of oestrogens on adipose tissue is connected with the stimulation of the releasing of other hormones which increase HSL activity. There are many which belong to this group of hormones including catecholamines, growth hormone and glucagon. In liver, 17- beta oestradiol regulates the synthesis of structural apolipoproteins for VLDL(very low-density lipoproteins) and HDL (high density lipoproteins). 17-beta oestradiol regulates lipid metabolism in adipocytes and hepatocytes and thus modulates the concentration of lipid substances in plasma. The lack of 17- beta oestradiol likely leads to various lipid metabolism disorders in women after menopause ${ }^{8}$.

Many studies have shown that oestrogenic signalling may be responsible for obesity in menopausal women. The chances of menopausal women developing obesity and metabolic abnormalities is three times more than premenopausal women. The hormones leptin, insulin, sex hormones and growth hormone influence appetite, metabolism and body fat distribution. The increased production of oestrogens in the fat of older women who are obese is associated with an increase in breast cancer risk. This indicates that the source of oestrogen production is important ${ }^{9}$. The accumulation of abdominal fat puts both men and women at a heightened risk of cardiovascular disease, diabetes and insulin resistance. Women are protected from these negative consequences as long as they carry their weight in their hips and saddle bags. But when they go through menopause and the body fat shifts to the abdomen, they have to start battling all of these medical complications ${ }^{10}$.

Menopause occurs as a result of a genetically programmed loss of ovarian follicles. The earliest stage of menopause, typically around two years prior to the onset of menstrual irregularity, begins when inhibin B concentrations fall due to a decreased number of follicles, which causes serum follicle stimulating hormone (FSH) levels to rise. During this transition, oestradiol 
secretion is relatively preserved (normal or high oestradiol levels) due to an increase in aromatase activity. As menopause progresses, serum concentration of FSH and oestradiol change dramatically, high FSH and low oestradiol levels occur as a result of decreased aromatase and inhibin B activity which may be initiated by the hypothalamus and result in the clinical manifestation of menopause ${ }^{11}$. The oestrogen levels of a woman are inversely proportional to her weight in menopause. A four-year study of newly menopausal healthy women showed increase in terms of adipose tissue. There was decrease in oestradiol. In vitro study of female mice surgically thrust into menopause by removal of ovaries was conducted. The study showed that oestrogen treated mice maintained constant weight. Those mice which were deprived of oestrogen rapidly gained weight. Studies have shown that oestrogen incorporates crucial elements into the DNA responsible for weight control. The absence of oestrogen and the crucial elements leads to progressive obesity ${ }^{12}$.

\section{DISCUSSION}

Charaka mentions that Vata is fuelled by the Medo Dhatu and increases the Agni leading to increased appetite and more intake of food. Stored adipose tissue acts as an endocrine gland which may have receptor cells for hormones like cortisol. Leptin is one more hormone which increases appetite. According to the Tridosha (three humors) theory Vriddhavastha (old age) has predominance of Vata. Sthoulya is a disease of Kapha Dosha and Medo Dushya (adipose tissue that undergoes vitiation). So, the management of Sthoulya during Rajo Nivrutti has to be simple. But in this case, there is involvement of hormones like oestrogen, testosterone. Because of the cessation of oestrogen there is an increase in the adipose tissue especially around abdomen and hips. Hence a comprehensive understanding of menopause and the physiological change it brings about in the body is necessary to understand menopausal obesity. The term Javoparodha carries relevance. As elaborated by Chakrapani, Jaroparodha as early onset of old age can be corelated with the onset of menopause. The deposition of adipose tissue in areas like buttocks, abdomen and breasts has been mentioned. According to modern studies only the androgynous type of obesity is wrought with risk of other non-communicable diseases. Focus on fat metabolism is needed as Sthoulya is considered a Medo Roga (disease of adipose tissue) which involves Medo Dhatu ${ }^{13}$. In many texts, Javoparodha has been explained as difficulty in movements or sluggish movements ${ }^{14}$.There is opinion that Medo Dhatu in excess may cause depletion of next Dhatus (tissue or system) like Asthi (bone), Majja (bone marrow) and Shukra (semen) ${ }^{15}$. Medo Dhatu has predominance of Prithvi (element of earth) and Ap Mahabhuta (element of water) and is similar to Kapha Dosha (Kapha humor) ${ }^{16}$.According to some researchers, Baddha Meda (fixed fat) is referred to as fat deposition in certain areas like hips, buttocks and abdomen. Abaddha Medas is the fat circulation in the form of lipids like cholesterol, triglycerides, HDL (high density lipoproteins), LDL (low density lipoproteins), VLDL (very low-density lipoproteins) ${ }^{17}$. Sushruta explains that menstrual blood is the manifestation of Rasa Dhatu. But Rajo Nivrutti is brought about by the depletion of all the Dhatus due to old age ${ }^{18}$. Sushruta describes the nature of Artava (menstrual blood) as $A g$ neya (possessing the nature of fire) ${ }^{19}$. Though there is depletion of all the other Dhatus, due to old age there will be no manifestation of Artava. Since Artava is $\mathrm{Ag}$ neya (possessing element of fire) in nature there will be depletion of Agni Guna (properties of fire element) in the body. This may cause increase of Kapha and in turn may increase Medo Dhatu. As a result, in spite of depletion of all the Dhatus there will be Medo Dhatu Vardhana Gunas (factors which increase adipose tissue).

While explaining the management of Sthoulya, Vagbhata says that there is no medicine for Sthoulya ${ }^{20}$ which underlines the difficulty in treatment. While explaining the general line of treatment Vagbhata says whatever is detrimental to Meda, Vata and Kapha has to be followed ${ }^{21}$.

Because of the obstruction to the path of Kapha and Meda, other Dhatus will not be nourished. Dalhana explains that other Dhatus refer to bones which may suggest osteoporosis and weakness of skeletal system, decreased Shukra may refer to low sexual drive. So, the 
life expectancy decreases, the person may suffer from diabetic carbuncles, fever, fistula in ano, abscesses, cerebro vascular accidents and finally dies. All the complications occur due to the blockage of channels. Therefore, the aetiological factors need to be reversed $^{22}$. The line of treatment should incorporate medicines and diet which have Agni Mahabhuta. They should be Medo Hara (alleviates adipose tissue) and Kapha Hara (alleviates Kapha vitiation) in action. Since menopause results in the depletion of Asthi (bone) and Majja Dhatus (bone marrow), diet and lifestyle modifications are to be advised for supplementing these Dhatus. Stress related weight gain can be treated by finding and reducing sources of stress. Relaxation techniques reduce the harmful effects of stress on the body. As stress decreases, cortisol is brought down. There is decreased appetite, insulin resistance is brought down and as a result fat storage decrease.

\section{CONCLUSION}

Sthoulya alone is difficult to treat and menopausal obesity more so because of many physiological changes in the body due to hormonal variations. The body has depletion of all other tissues except muscular and adipose tissue. Hence the management of Sthoulya of Rajo Nivrutti should take care of the Agni, Vata and Kapha Dosha as well as Medo Dhatu. Hence a comprehensive diet plan which consists of Agni Guna which increases Agni and alleviates Kapha, Vata and Meda needs to be planned. Daily regimen of exercise, proper sleep and a disciplined routine are helpful in menopausal obesity. Procedures like Sarvanga Udwartana (whole body massage with medicinal dry powder) and Bashpa Sweda (sudation in steam chamber) may reduce subcutaneous fat. Lekhana Basti (medicated enema) may help in reducing visceral fat and Tikta Dravya Basti (enema consisting of bitter ingredients) may help in increasing bone density (Asthi Vruddhi). Use of Kshudra Dhanyas (millets) which contain soluble fibre helps in reducing cholesterol and triglycerides.

\section{REFERENCES}

1. Hari Shastri Paradakara (edited), Anna Moreswara Kunte, Krsna Ramachandra Shastri Navare (Collated), Astanga Hrdayam by Vagbhata, Arunadatta, Hemadri (commentary), Chaukhambha Orientalia, Varanasi, ISBN: 978-81-7637-017-2, Reprint:2017, Sutra Sthana, Ch 1 Verse 7, Pg 363

2. Harish Chandra Kushwaha (edited)Caraka Samhita of Agnivesha, Caraka, Dridhabala, Chaukhambha Orientalia, Varanasi, ISBN: 978-81-7637-149-0, Reprint: 2014, Sutrasthana Ch11 verse 4 Pg 309

3. Hari Shastri Paradakara (edited), Anna Moreswara Kunte, Krsna Ramachandra Shastri Navare (Collated), Astanga Hrdayam by Vagbhata, Arunadatta, Hemadri (commentary), Chaukhambha Orientalia, Varanasi, ISBN: 978-81-7637-017-2, Reprint:2017, Sutra Sthana Ch 11 Verse 10, pg 184

4. Hari Shastri Paradakara (edited), Anna Moreswara Kunte, Krsna Ramachandra Shastri Navare (Collated), Astanga Hrdayam by Vagbhata, Arunadatta, Hemadri (commentary), Chaukhambha Orientalia, Varanasi, ISBN: 978-81-7637-017-2, Reprint:2017, Sutra Sthana Ch 14 Verse 20, Pg 225

5. Jadavji Trikamji (edited), Sushruta Samhita of Sushruta, Dalhana (commentary), Chaukhambha Orientalia, ISBN 978-81-7637-162-9, Reprint: 2014, Shaareera Sthana Ch 3 verse 11 Pg 351

6. Hari Shastri Paradakara (edited), Anna Moreswara Kunte, Krsna Ramachandra Shastri Navare (Collated), Astanga Hrdayam by Vagbhata, Arunadatta, Hemadri (commentary), Chaukhambha Orientalia, Varanasi, ISBN: 978-81-7637-017-2, Reprint:2017, Shareera Sthana Ch1 verse 7 Pg 363

7. Margaret $\mathrm{N}$ Groves, how hormones lead to obesity, April 29, 2013-Zrt lab.com/blog/archive/hormones and obesity/ last accessed 13/10/20.

8. Szafran et al. the role of oestrogens in hormonal regulation of lipid metabolism in women, $\operatorname{Pr}$ ze gl Lek 1998; 55(5): 266-70 PMID: 9741194

9. www.betterhealth.vic.gov.acl- last accessed 13/10/20

10. Deborah j Clegy et al. American chemical society. Revealing estrogen'S secret role in obesity. Science daily, 20 August 2007 www.sciencedaily.com/releases/2007/08/070820145348.htm- last accessed $\underline{13 / 10 / 20}$

11. Davis et al. managing menopausal symptoms in the geriatric population: Moving beyond menopausal hormone therapy. Consultant vol 17- No.10 October 2009

12. James Woods, Editor, Perifacts @ OB/GYN Academy, UR Medicine Menopause and Women'S health, 5/1/2015@2020 University of Rochester Medical Center Rochester, NY. Last accessed 17/10/20. 
13. Triveni Raina et al.Mode of action of Amritadya Guggulu in the management of Sthoulya W.S.R to obesity, Int J.Ayur Pharma Research, 2018;6(8):49-54.

14. Patley et al. Ayurvedic aspect of Sthoulya and its management, WJPR, 7(16),133-142

15. Rao Veena $G$ et al. Effect of Moorchita Tila Taila Prayoga in Sthoulya- An interventional clinical study, EJPMR, 2018, 5(02), 387-393

16. Bishnu et al. Management of Sthaulya (obesity) through Ayurveda and Yoga, WJPR,2018; 7(17) 356-367

17. Rajan $\mathrm{N}$ et al, Int. J of Allied Med.Sci and Clin. Research Vol 7 (3) 2019:933-938

18. Jadavji Trikamji (edited), Sushruta Samhita of Sushruta, Dalhana (commentary), Chaukhambha Orientalia, ISBN 978-81-7637-162-9, Reprint: 2014, Sutra Sthana Ch 24, verse 6 Pg 59

19. Jadavji Trikamji (edited), Sushruta Samhita of Sushruta, Dalhana (commentary), Chaukhambha Orientalia, ISBN 978-81-7637-162-9, Reprint: 2014, Sutra Sthana Ch 24 verse 7 Pg 59

20. Hari Shastri Paradakara (edited), Anna Moreswara Kunte, Krsna Ramachandra Shastri Navare (Collated), Astanga Hrdayam by Vagbhata, Arunadatta, Hemadri (commentary), Chaukhambha Orientalia, Varanasi, ISBN: 978-81-7637-017-2, Reprint:2017, Sutra Sthana Ch 14, verse 31 pg 227

21. Hari Shastri Paradakara (edited), Anna Moreswara Kunte, Krsna Ramachandra Shastri Navare (Collated), Astanga Hrdayam by Vagbhata, Arunadatta, Hemadri (commentary), Chaukhambha Orientalia, Varanasi, ISBN: 978-81-7637-017-2, Reprint:2017, Sutra Sthana Ch 14 verse 21 pg 226

22. Jadavji Trikamji (edited), Sushruta Samhita of Sushruta, Dalhana (commentary), Chaukhambha Orientalia, ISBN 978-81-7637-162-9, Reprint: 2014, Sutra Sthana Ch 15 verse $32, \operatorname{Pg} 73$.

\section{Source of Support: Nil \\ Conflict of Interest: None Declared}

How to cite this URL: Usha K S \& Gurdip Singh: Menopause (Rajo Nivrutti) And Obesity (Sthoulya) - A Critical Review. International Ayurvedic Medical Journal \{online\} 2020 \{cited November, 2020\} Available from: http://www.iamj.in/posts/images/upload/5115 5120.pdf 